\title{
High Throughput Screening and Characterization Methods of Jordanian Oil Shale as a Case Study
}

\author{
Ziad Abu El-Rub 1,*(D), Joanna Kujawa 2 ${ }^{(1)}$, Esra'a Albarahmieh ${ }^{1}$, Nafisah Al-Rifai ${ }^{1}$, \\ Fathieh Qaimari ${ }^{3}$ and Samer Al-Gharabli ${ }^{1, *}$ \\ 1 Pharmaceutical and Chemical Engineering Department, German Jordanian University, \\ Amman 11180, Jordan \\ 2 Faculty of Chemistry, Nicolaus Copernicus University in Toruń, 7 Gagarina Street, 87-100 Torun, Poland \\ 3 Chemical and Mineral Analysis Division, Jordan Ministry of Energy and Mineral Resources, \\ P.O. Box 7, Amman 11118, Jordan \\ * Correspondence: ziad.abuelrub@gju.edu.jo (Z.A.E.-R.); samer.gharabli@gju.edu.jo (S.A.-G.); \\ Tel.: +962-6-429-4412 (Z.A.E.-R.); +962-6-429-4404 (S.A.-G.)
}

Received: 7 July 2019; Accepted: 14 August 2019; Published: 16 August 2019

\begin{abstract}
Oil shale is an important possible solution to the problem of energy in Jordan. To explore the technical and the economic feasibility of oil shale deposits, numerous samples are analyzed using the standard Fischer Assay (FA) method. However, it would be useful to develop faster, cheaper, and reliable methods for determining the oil content of oil shale. Therefore, the aim of this work was to propose and investigate rapid analytical techniques for the screening of oil shale deposits and to correlate them with the FA method. The Omari deposit located east of Jordan was selected as a case study for analysis using thermogravimetric analysis (TGA) coupled with Fourier-transform infrared (FTIR), differential scanning calorimetry (DSC), elemental analysis, X-ray fluorescence (XRF), X-ray diffraction (XRD), scanning electron microscopy (SEM), and energy-dispersive X-ray (EDX) analysis. Results obtained from the TGA method were linearly correlated with FA with high regression factor $\left(R^{2}=0.99\right)$; a quadratic correlation $\left(R^{2}=0.98\right)$ was maintained between the FA and the elemental hydrogen mass content, and a quadratic correlation $\left(R^{2}=0.97\right)$ was found between the FA and the aliphatic hydrocarbons (FTIR peak at $2927 \mathrm{~cm}^{-1}$ ) produced in the pyrolysis zone. Although other techniques were less correlated, further investigation might lead to better results. Subsequently, these correlated techniques can be a practical alternative to the conventional FA method when, in particular, specific correlation is made for each deposit.
\end{abstract}

Keywords: oil shale; Jordan; TGA; FTIR; DSC; elemental analysis; XRF; XRD; SEM; EDX

\section{Introduction}

Jordan is a country in the Middle East region that suffers from a lack of conventional fossil energy sources. In 2017, the country imported $94 \%$ of its energy needs, equivalent to $8.5 \%$ of its gross domestic product (GDP) [1]. To increase energy security, the kingdom has been encouraging investments in renewable energy — mainly solar and wind — and alternative energy that is principally oil shale. However, the economic feasibility of these projects is affected by crude oil prices, technical challenges, and environmental considerations.

Oil shale can be defined as sedimentary rocks including organic matter disseminated in a mineral matrix. The organic matter is combustible hydrocarbons, predominantly kerogen, which is insoluble in common organic solvents [2,3].

The kingdom is ranked the sixth country in the world in oil shale resources, with more than 70 billion tons of proven reserves distributed over $60 \%$ of Jordan's territory [4]. Recent scientific reports 
highlighted that Jordan can produce around 34 billion barrels of shale oil from its resources [5]. Despite the fact that these significant amounts were discovered in the early 20th century, Jordan's experience in exploiting oil shale commercially is relatively modest. The first commercial oil shale project in Jordan will be the exploitation of Attarat Umm Ghudran deposit by direct burning to produce $470 \mathrm{MW}$ electricity by the year 2020. Furthermore, subsurface in-situ retorting has been investigated by Jordan Oil Shale Company (JOSCO), which is a wholly-owned subsidiary of Royal Dutch Shell.

Jordan has given international companies the license of commercial exploitation for several oil shale deposits. These deposits are distributed at more than 24 locations across Jordan, as shown in Figure 1. However, most commercial areas are in the central region of Jordan (El-Lajjun, Sultani, Attarat Um Ghudran, and Wadi Maghar) [4,6]. The possibility for commercially exploiting a deposit depends on the applied technology and the type of application. Generally, the oil shale can conventionally be exploited by either retorting to produce oil or by direct combustion to generate electricity. From an economic perspective, the retorting process requires an oil content of more than $5 \mathrm{wt} . \%$, whereas the direct burning process requires an oil shale minimum calorific value of $3 \mathrm{MJ} / \mathrm{kg}$ [7]. The Jordanian oil shale is suitable for both applications, as it has an average oil content of $10 \mathrm{wt} . \%$ and a minimum calorific value of $6 \mathrm{MJ} / \mathrm{kg}$. Moreover, the average sulfur content in the Jordanian oil shale is about $3 \mathrm{wt} . \%$ of the rock weight or $9 \mathrm{wt} . \%$ relative to the kerogen content. The presence of sulfur and other compounds such as nitrogen, oxygen-containing compounds, and diolefins reduces the stability and the quality of the produced shale oil, which complicates the shale oil treatment process and decreases economic feasibility [7]. Therefore, this shale oil needs to be upgraded to produce stable liquid fuel [2]. Upgraded oil shale can be utilized more efficiently and economically in power generation as well as in oil production [8].

Oil shale deposits usually have large areas, different depths, and varying oil content. Therefore, to exploit such complex resources, it becomes critical to find high throughput screening methods. There are a variety of physical and chemical methods that are used to screen and characterize oil shale $[9,10]$. These methods include solvent extraction, microscopic methods [11], physical (color, specific gravity, thermophysical properties), elemental analysis $(\mathrm{C}, \mathrm{H}, \mathrm{N}, \mathrm{O}, \mathrm{S}$ ), thermal degradation (Fischer Assay, thermogravimetric analysis, isothermal pyrolysis, pyrolysis flame ionization detection) [12,13], chemical degradation, chromatographic procedures, mass spectrometry, Raman spectroscopy [14], laser-induced techniques [15], and modern infrared techniques [16]. However, each method has its own shortcomings that limit its application. Thus, the choice of the optimal method depends on cost, accuracy, reliability, speed, online capability, and level of operator intervention.

El-Hasan et al. [5] presented the utilization of synchrotron-supported techniques to analyze Jordanian oil shale deposits. Synchrotron-based X-ray absorption near-edge structure (XANES) was used for chromium and arsenic analysis [5]. For the speciation analysis of solids focused on trace elements in environmental samples, synchrotron beamlines have the potential of competing in X-ray diffraction, fluorescence, as well as absorption spectroscopy [17]. Considering the study of kerogens structure, cross-polarized magic angle spinning (CP/MAS) and X-ray photoelectron spectroscopy (XPS) techniques are very useful. ${ }^{13} \mathrm{C}$ NMR was utilized with high efficiency to determine the carbon skeletal structure in fossil resources [18,19]. XPS, however, was successfully implemented in the investigation of the forms of organic heteroatoms $(\mathrm{O}, \mathrm{S}, \mathrm{N})$ in the complex matrix [20,21]. The Fischer Assay (FA) method is the standard test method for determining the oil yield in the oil shale deposit [22-25]. Despite being the standard method, it has several disadvantages, including inability to measure the maximum amount of oil in a given oil shale [26], expensive laboratory setup, strict laboratory safety measures due to evolved $\mathrm{H}_{2} \mathrm{~S}$ and other toxic gases, relatively large sample size (100 g), prolonged analysis time $(\sim 2 \mathrm{~h})$, dependency on retort parameters (particle size, heating rate, heat and mass transfer limitations, etc.), and lower yield compared with commercial retorts [10]. Therefore, it would be advantageous to develop faster, cheaper, and more reliable methods for determining the oil content of oil shale.

The aim of this study was to find high throughput screening methods for analyzing the oil content of oil shale as an alternative for the conventional FA method. The Omari oil shale deposit in 
Jordan was characterized and adopted as a case study. A variety of techniques were screened for this purpose, including thermogravimetric analysis (TGA) coupled with Fourier-transform infrared (FTIR), differential scanning calorimetry (DSC), X-ray diffraction (XRD), scanning electron microscopy (SEM), and energy-dispersive X-ray (EDX).

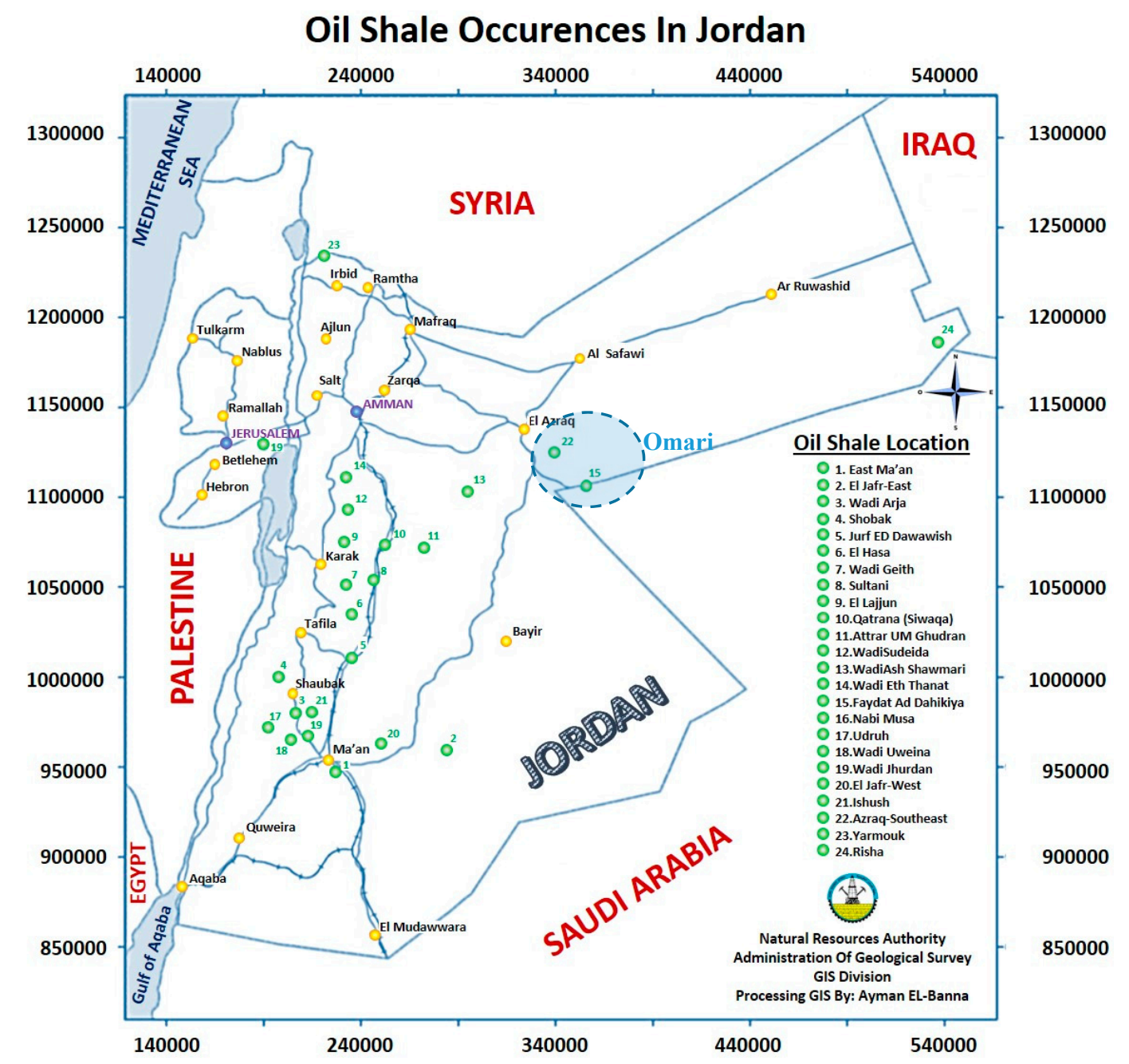

Figure 1. Map of the major oil shale deposits in Jordan. Adapted from reference [4].

\section{Materials and Methods}

Crushed and sieved oil shale samples were collected from the Omari deposit, which is located southeast of Amman and nearly reaches the Iraqi borders, as shown in Figure 1. Moreover, the oil yield was determined using the FA method according to standard test method ASTM D3094-90. In this method, $100 \mathrm{~g}$ of a dried sample of oil shale was ground into less than $2.38 \mathrm{~mm}$ particles and heated in a small aluminum oven (retort) to $500^{\circ} \mathrm{C}$ at a rate of $12{ }^{\circ} \mathrm{C} / \mathrm{min}$ and held at the final temperature for $40 \mathrm{~min}$. The resulting vapors of oil, gas, and water were passed through a condenser and cooled with ice water into a graduated centrifuge tube to separate the oil from the water and measure the oil yield [27].

Thermal properties of the samples were evaluated using thermoanalyzer Jupiter STA 449 F5 (Netzsch, Germany) coupled with FTIR spectrometer (Vertex 70V Bruker Optik, Germany). The different samples obtained from the deposit were placed in vials and given a number from OS1 to OS6. Three samples from each vial were thermally analyzed. We assumed that these homogeneous and representative samples could be considered as an identical sample where the standard deviation of the thermal analysis is calculated. Thermogravimetric analysis (TGA), derivative thermogravimetry (DTG), 
and differential thermal analysis (DTA) were accomplished over a temperature range of $25-1100{ }^{\circ} \mathrm{C}$ under an ambient atmosphere of nitrogen with a heating rate of $20^{\circ} \mathrm{C} / \mathrm{min}$. TGA and DTG were used for the thermal stability characterization of the investigated samples. DTA gives information about the changes in the energy of the materials (specific heat capacity and enthalpy). The gas products from TGA were simultaneously analyzed on the FTIR spectrometer with a resolution of $4 \mathrm{~cm}^{-1}$ and a number of 16 scans $/ 0.3^{\circ} \mathrm{C}$ by the implementation of Gram-Shmidt diagram.

Elemental analysis was done on Vario MACRO CHN ELEMENTAR Analysensysteme GmbH. Furthermore, the chemical composition of major oxides in the oil shale samples was analyzed by XRF using the sequential wavelength dispersive X-ray fluorescence spectrometer (Bruker S4 Pioneer, Germany). The identification of the structure of the crystalline solid shales and their mineral composition was examined by using the D4 ENDEAVOR X-ray Diffractometer from Bruker. The method of peak area against calibrated curves was used.

The Quantax 200 with XFlash 4010 detector (Bruker AXS machine, Czech Republic) was used for scanning electron microscopy (SEM) imaging of samples. SEM imaging was performed with a secondary electrons (SE) detector under high vacuum $<6 \times 10^{-4} \mathrm{~Pa}$. Before measurements, oil shale samples were sputtered with a nanolayer $(10 \mathrm{~nm})$ of gold for morphology determination. For EDX measurements, the microscope 1430 VP LEO Electron Microscopy Ltd (England) was used (non-sputter samples were tested).

\section{Results and Discussion}

The absence of an ideal method to analyze oil shale has led to the usage of a variety of methods to overcome various limitations of the popular method(s) of analysis. The results of these analyses are discussed here.

\subsection{Fischer Assay}

Six oil shale samples labeled from OS1 to OS6 were obtained from the Omari deposit covering a wide range of oil content in Jordanian oil shale, which has an average content of about $10 \mathrm{wt.} \%$ [7]. The oil yield was determined using the standard FA method. Table 1 shows that the oil content of the tested samples varied between 2.9 to $12.7 \mathrm{wt}$. $\%$, and the oil density varied between 0.951 to $0.967 \mathrm{~g} / \mathrm{mL}$. Furthermore, it was noticeable that the shale oil content was inversely proportional to its density, which could be related to the lower density of oil compared with the inorganic matter.

Table 1. Fischer Assay (FA) analysis of oil shale (OS) samples.

\begin{tabular}{cccc}
\hline \multirow{2}{*}{ Sample } & \multicolumn{2}{c}{ Fischer Assay } & OS Density \\
\cline { 2 - 4 } & $\mathbf{( g / 1 0 0 ~} \mathbf{g})$ & $\mathbf{( m L / 1 0 0 ~} \mathbf{g})$ & $\mathbf{( g / m L )}$ \\
\hline OS1 & 2.90 & 3.00 & 0.967 \\
OS2 & 5.31 & 5.50 & 0.964 \\
OS3 & 7.00 & 7.25 & 0.966 \\
OS4 & 9.10 & 9.48 & 0.960 \\
OS5 & 11.20 & 11.70 & 0.957 \\
OS6 & 12.70 & 13.35 & 0.951 \\
\hline
\end{tabular}

\subsection{Thermogravimetric Analysis}

TGA is a rapid technique widely used to record weight loss of oil shale as a function of temperature. DTA is a complementary technique usually used in the same TGA instrument to represent the temperature difference developed between the oil shale sample and a reference. Both techniques can be used to provide important information on the behavior of heated oil shale samples and assign the maximum temperature where the basic thermodecomposition of kerogen occurs. Moreover, thermogravimetric analysis coupled with FTIR (TGA-FTIR) as a detector was used for online identification of evolved gases of the TGA in the infrared spectrometer gas cell. This coupling 
can be useful in studying the mechanism of kerogen pyrolysis, which gives a real-time identification of TGA products at different temperatures. Furthermore, gases evolved at the temperature observed for oil weight loss (TGA/DTG) were coupled with the thermal transitions gained by coupling to the DSC. The simultaneous DSC analysis was also associated with endothermic transitions around the region of gas evolving from oil pyrolysis. Additionally, the variation of the amount of evolved gases during pyrolysis and thermal degradation of the oil shale sample could be detected by Gram-Schmidt thermogram where the FTIR absorption intensity of evolved gases was plotted as a function of temperature.

\subsubsection{TGA and DTG}

All six oil shale samples collected from Omari deposit were subjected to the above-mentioned techniques under a nitrogen environment over a temperature range of 25 to $1100{ }^{\circ} \mathrm{C}$ and at a heating rate of $20^{\circ} \mathrm{C} / \mathrm{min}$. In general, all samples showed similar trends with slight discrepancies in the pyrolysis region. Figure 2A shows representative TGA and DTG curves of one of the oil shales sample (OS6, FA $12.70 \mathrm{wt} . \%$ ). The total weight loss was $52.0 \mathrm{wt} . \%$, which passed through three distinct stages: (1) drying, (2) pyrolysis, and (3) mineral decomposition. In the drying stage (up to $370{ }^{\circ} \mathrm{C}$ ), less than $1.5 \mathrm{wt} . \%$ was lost due to moisture loss, which included surface moisture, shirking core evaporation of moisture, and the moisture in small capillaries of the oil shale particles [2]. In the pyrolysis stage $\left(370-560^{\circ} \mathrm{C}\right)$, a weight loss of $14.0 \mathrm{wt} . \%$ was recorded. Here, kerogen was thermally decomposed to form shale oil, shale gas, and char. Furthermore, the mineral matter may have decomposed to produce carbon dioxide and release combined water. Finally, in the mineral decomposition stage (more than $600{ }^{\circ} \mathrm{C}$ ), about $31.0 \mathrm{wt} . \%$ loss was observed. In this stage, the different minerals, e.g., calcite, kaolinite, and dolomite, decomposed to form mainly carbon dioxide and the metal oxide. Moreover, employing the first derivative for the TGA to generate the corresponding DTG showed an average maximum temperature of pyrolysis $\left(T_{\max }\right)$ of $472.4 \pm 9.1{ }^{\circ} \mathrm{C}$.
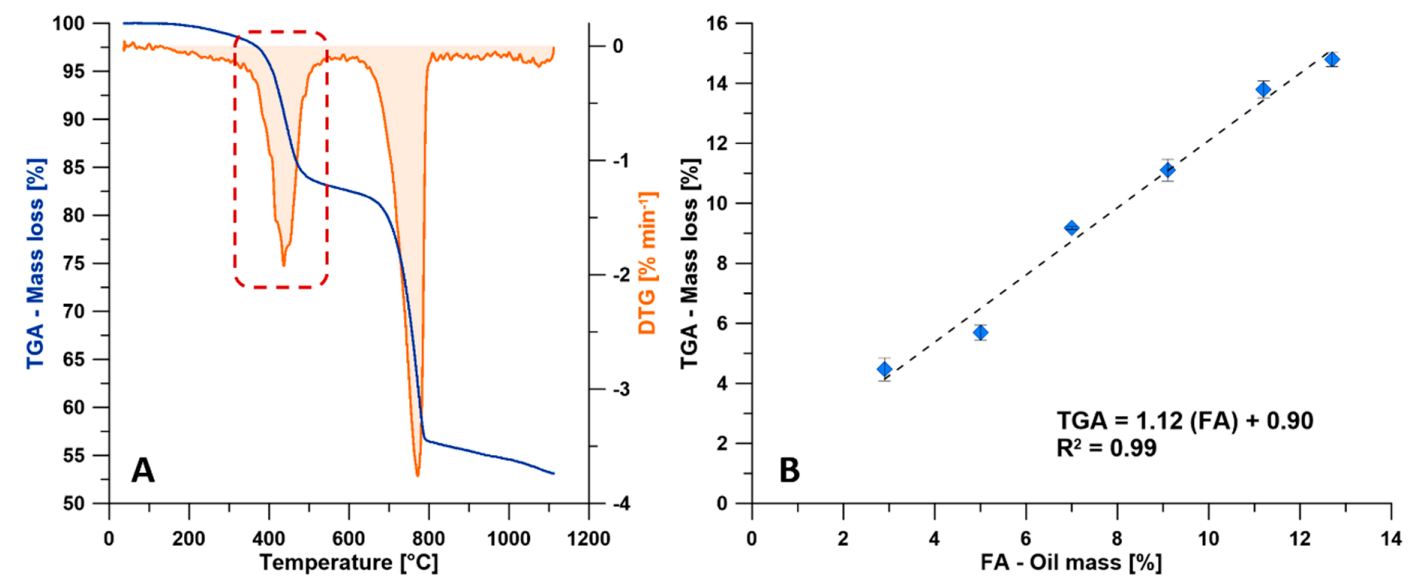

Figure 2. (A) Representative decomposition curve of OS6 (FA $12.7 \mathrm{wt}$ \% $\%$ ) using thermogravimetric analysis (under nitrogen). The measured values of decomposition and oil release around $435{ }^{\circ} \mathrm{C}$ were calculated and optimized through comparison of the derivative thermogravimetry (DTG) curves at a heating rate of $20^{\circ} \mathrm{C} / \mathrm{min}$; the solid line represents the thermogravimetric analysis (TGA) curve, and the dashed line represents the first derivative thermogravimetric (TG) curve. (B) Correlation curve with corresponding oil content in wt.\% from Fischer Assay plotted against the measured oil using thermogravimetric analysis showed a near-perfect linear fitting for oil content detection from $2.9 \mathrm{wt} . \%$ to 12.7 wt. $\%$.

When correlating the TGA mass loss in the pyrolysis region $\left(370-560{ }^{\circ} \mathrm{C}\right)$ with the FA oil content, an outstanding linear correlation $\left(R^{2}=0.99\right)$ between the two analysis methods was established (Figure 2B). Each point in Figure 2B represents an average of three trials, and the corresponding error bars demonstrate the precision of the experiments. Therefore, the TGA method can be used as a reliable 
alternative for the FA method. Because kerogen type and mineral matrix might vary according to the deposit type [9], such correlation should be utilized based on a specific calibration. Moreover, the produced correlation in Figure 2B can be also described as in Equation (1).

$$
F A=0.894 \times T G A-0.802
$$

where FA denotes the oil weight percent in the oil shale determined by the FA method, and TGA represents the percent of weight loss at the pyrolysis range. Such correlation is in accordance with the literature [28].

\subsubsection{TGA-FTIR}

Thermogravimetric analysis coupled with FTIR as a detector was used for online identification of evolved gases of TGA for all samples (OS1 to OS6). The analysis was repeated three times in the infrared spectrometer gas cell, and the average result for each sample is presented in Figure 3. The spectra showed two distinct regions: pyrolysis and mineral decomposition. During the pyrolysis region $\left(370-560{ }^{\circ} \mathrm{C}\right)$, the online FTIR spectrum showed broad bands between $2793-3060 \mathrm{~cm}^{-1}$ assigned to aliphatic (C-H stretching) with a peak area that was directly proportional to oil content. It is noteworthy to mention that $\mathrm{CO}_{2}$ also evolved at this stage (pyrolysis), which was confirmed by the broad bands between $2225-2410 \mathrm{~cm}^{-1}$ assigned to $\mathrm{CO}_{2}$ stretching with no obvious correlation related to the oil content of the samples. Furthermore, the dactyloscopic region $\left(500-1500 \mathrm{~cm}^{-1}\right)$ showed the characteristic peaks related to the inorganic and the organic matrix. In the second region (thermal decomposition), weak bands with respect to $\mathrm{C}-\mathrm{H}$ aliphatic stretching $\left(2793-3060 \mathrm{~cm}^{-1}\right)$ were shown, which could have been related to the low oil content remaining after pyrolysis. On the other hand, stronger bands were noticed for $\mathrm{CO}_{2}\left(2225-2410 \mathrm{~cm}^{-1}\right)$ due to the thermal decomposition of minerals, which produced $\mathrm{CO}_{2}$.

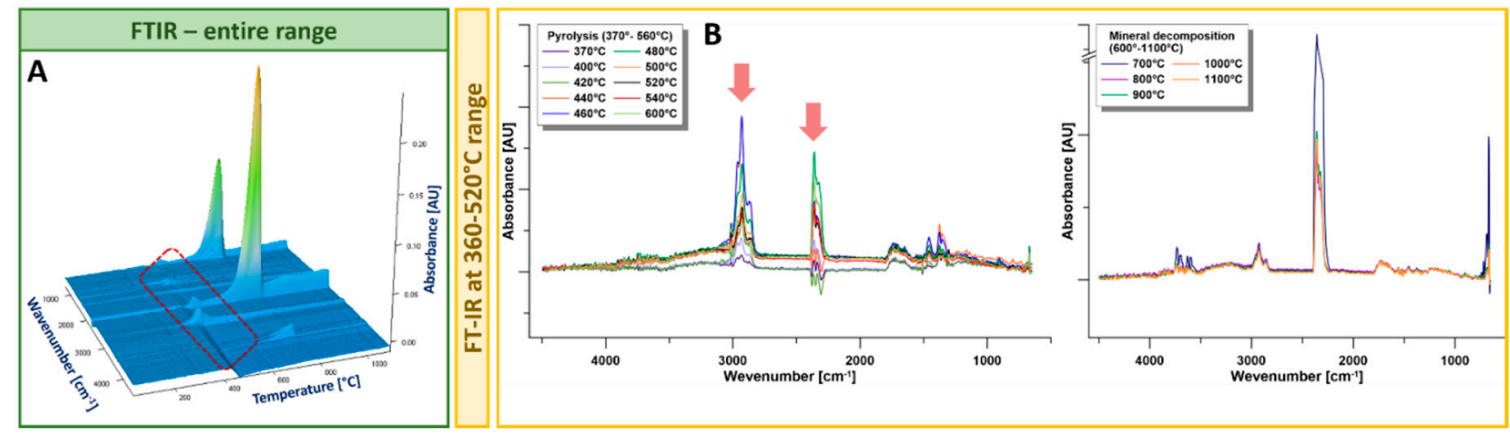

Figure 3. (A) 3D FTIR spectra collected as the function of temperature. (B) Detailed analysis of FTIR spectra of pyrolysis and mineral decomposition regions for a selected oil shale sample (OS6).

Figure 4A shows the 3D FTIR spectra between wavenumbers $\left(2800-300 \mathrm{~cm}^{-1}\right)$ for the six oil shale samples at the pyrolysis temperature range $\left(370-560^{\circ} \mathrm{C}\right)$. Quantification was done based on the integration of peak areas at $2927 \mathrm{~cm}^{-1}$ and $2342 \mathrm{~cm}^{-1}$ for the aliphatic hydrocarbons and $\mathrm{CO}_{2}$, respectively. Moreover, a correlation was made between the FA and the areas of the two sets of peaks, as shown in Figure 4B. It was obvious that a good quadratic correlation $\left(R^{2}=0.97\right)$ was maintained for the aliphatic hydrocarbons, as shown in Equation (2).

$$
Y=0.01009 \times X^{2}+0.02401 \times X+0.10568
$$

where $Y$ is the area of aliphatic hydrocarbons (peak at $2927 \mathrm{~cm}^{-1}$ ), and $X$ is the oil content of FA (wt.\%).

On the other hand, there was no clear correlation between the FA and the peak area of $\mathrm{CO}_{2}$ $\left(2342 \mathrm{~cm}^{-1}\right)$. However, two regions representing two mechanisms could be envisaged where there was a certain production of $\mathrm{CO}_{2}$ up to $\mathrm{FA} 7.0 \mathrm{wt} . \%$ and then it dropped. 

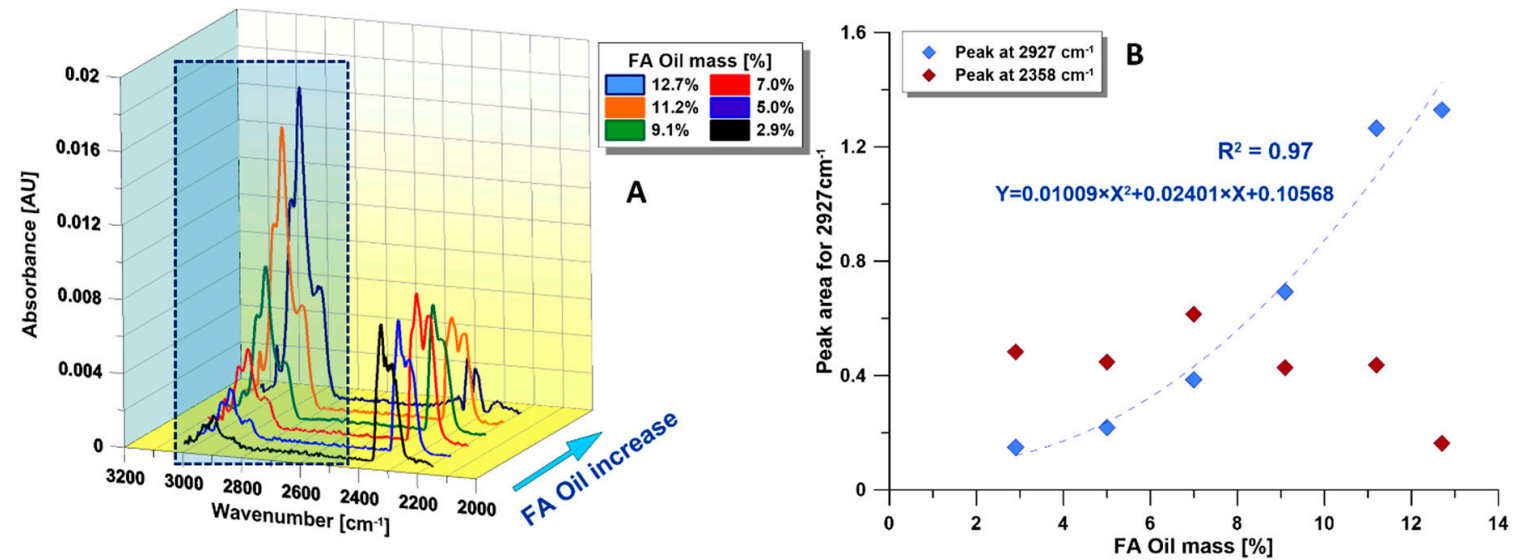

Figure 4. (A) Fourier-transform infrared (FTIR) spectra of the six oil shale samples at a temperature range of $370-560{ }^{\circ} \mathrm{C}$ and a heating rate of $20{ }^{\circ} \mathrm{C} / \mathrm{min}$, thus representing the major evolved gases. (B) Correlation curve between oil content in wt.\% from FA and the measured oil using dynamic FTIR at $2927 \mathrm{~cm}^{-1}$ and the measured $\mathrm{CO}_{2}$ at $2342 \mathrm{~cm}^{-1}$.

\subsubsection{DSC}

The amount of heat needed for retorting oil shale depends predominantly on its specific heat capacity. Therefore, DSC analysis was performed for all samples in triplicate. Figure 5 shows, using OS6 (FA 12.7\%) as an example, the DSC curve in addition to its TGA and DTG profiles. Results showed a similar DSC profile as a function of temperature for all samples. Furthermore, the peaks denoted an endothermic behavior in the pyrolysis zone $\left(370-560^{\circ} \mathrm{C}\right)$ with a heat capacity in the range of $(0.133-1.228 \mathrm{~J} /(\mathrm{g} \cdot \mathrm{K}))$ due to the thermal decomposition of kerogen. Moreover, the specific heat of oil shale depended on its type, which differed in the composition of mineral and kerogen content. However, for the same type, the specific heat increased with higher oil yield [2]. The same trend was found for all oil shale samples (OS1 to OS6), as exemplified in Figure 6, where specific heat capacity (Figure 6A) and enthalpy (Figure 6B) were directly proportional to the oil content.

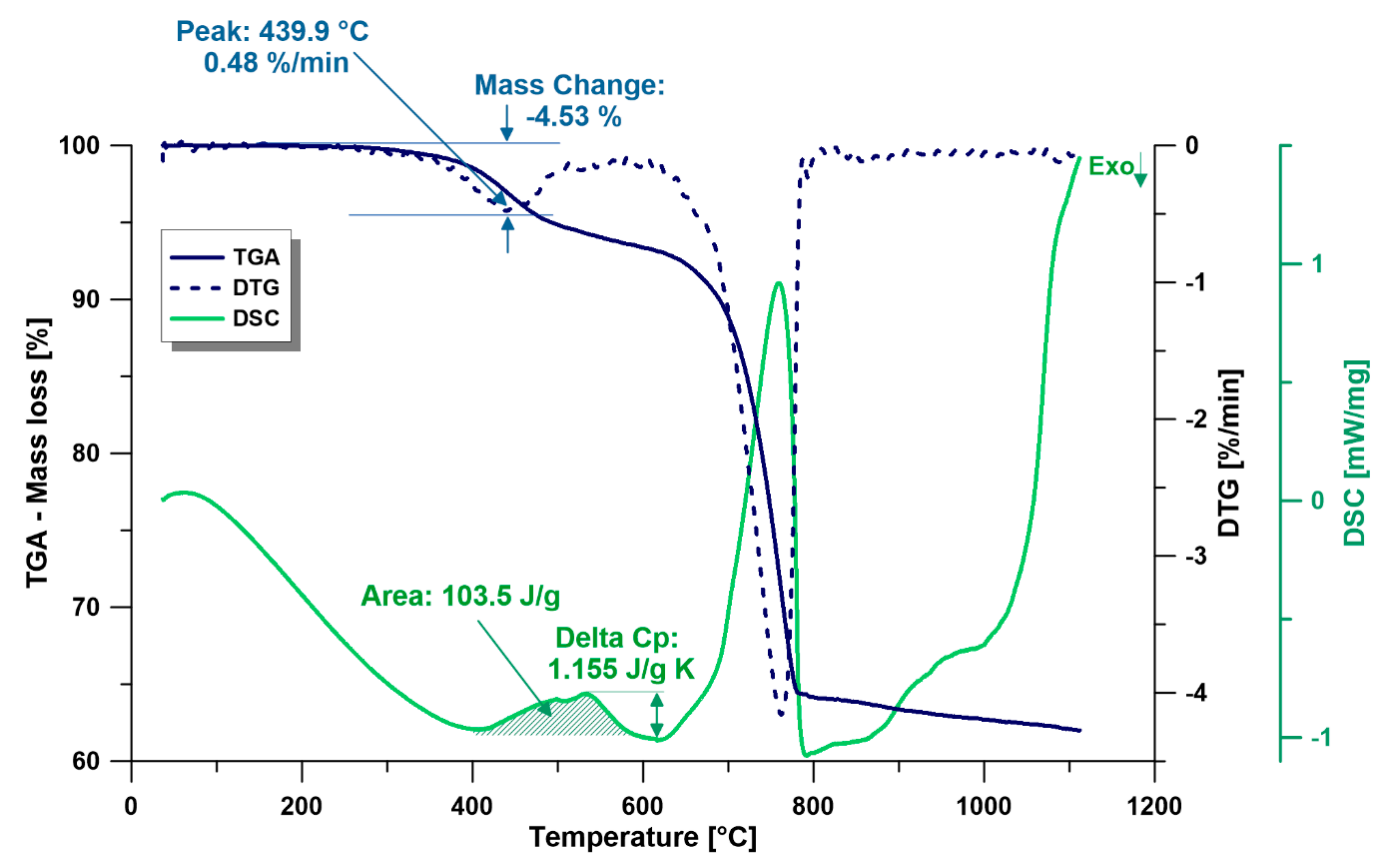

Figure 5. Representative TGA (mass loss) and DTG (mass change rate) curves for OS6 at a heating rate of $20^{\circ} \mathrm{C} / \mathrm{min}$ (solid blue and dashed blue lines, respectively) overlapped with differential scanning calorimetry (DSC) curve (solid green line) at a heating rate of $20^{\circ} \mathrm{C} / \mathrm{min}$. Left-hand side $y$-axis: TG curve. Right-hand side axis: DTG and DSC curves. 

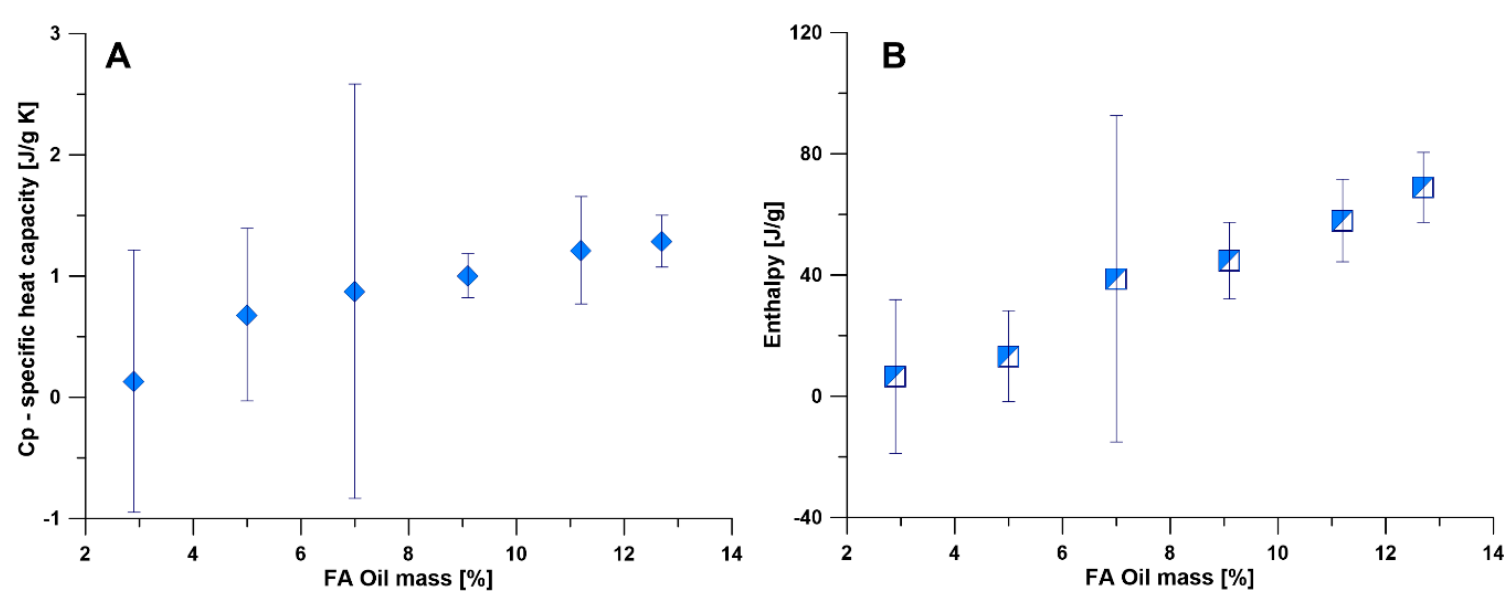

Figure 6. The relationship between the FA oil yield and (A) specific heat capacity and (B) enthalpy.

\subsubsection{Gram-Schmidt}

The amount of evolved gases resulted from the TGA could be detected and evaluated using the Gram-Schmidt thermogram [29]. For OS1 to OS6, Gram-Schmidt showed increase in the amount of evolved gases as a function of oil content, where the maximum gas productions were around $450{ }^{\circ} \mathrm{C}$ and $760{ }^{\circ} \mathrm{C}$ for the kerogen pyrolysis and the mineral decomposition, respectively (Figure 7, OS6 at a heating rate of $20^{\circ} \mathrm{C} / \mathrm{min}$ as an example). This behavior mirrored the peaks found in the DTG shown in Figure 2A. Figure 8 shows two sets of oil shales. The first group represents the low oil content (OS1-OS3), and the second is the high oil content (OS4-OS6). Although the first group contained lower oil content, it showed a higher amount of evolved gases. This might have been related to their lower heat capacity required by the oil for pyrolysis (as shown in Figure 6). Conversely, the second group produced fewer gases due to their higher heat capacity.

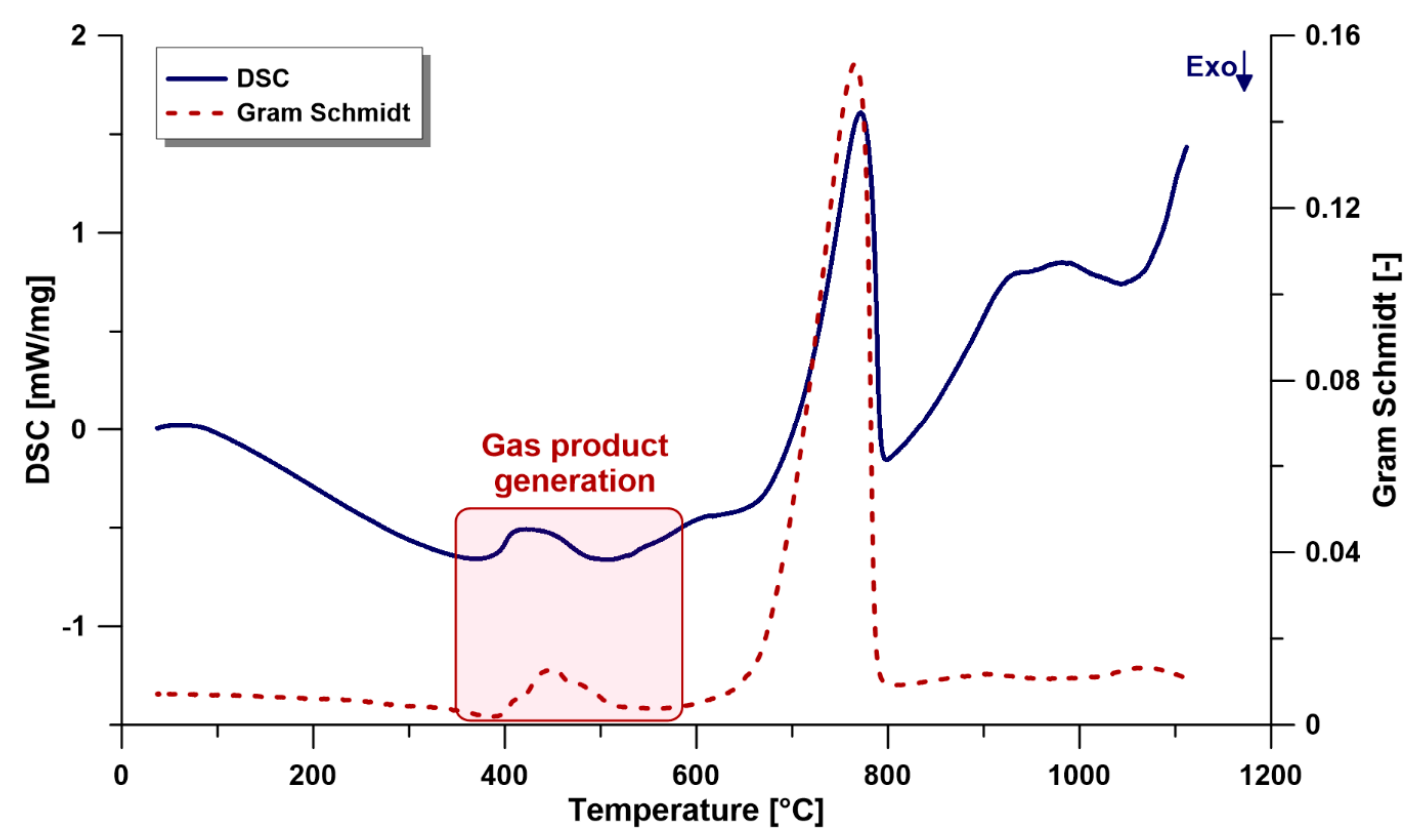

Figure 7. Triplicate heat flow rate (DSC) curve (solid line) and Gram-Schmidt (GS) signal (dashed line) of a representative OS6 (12.7 wt.\%), showing the region of gas evolving in the temperature range of $370-560{ }^{\circ} \mathrm{C}$ determined as the peak temperature. Heating rate of $20^{\circ} \mathrm{C} / \mathrm{min}$, gas atmosphere: nitrogen. 

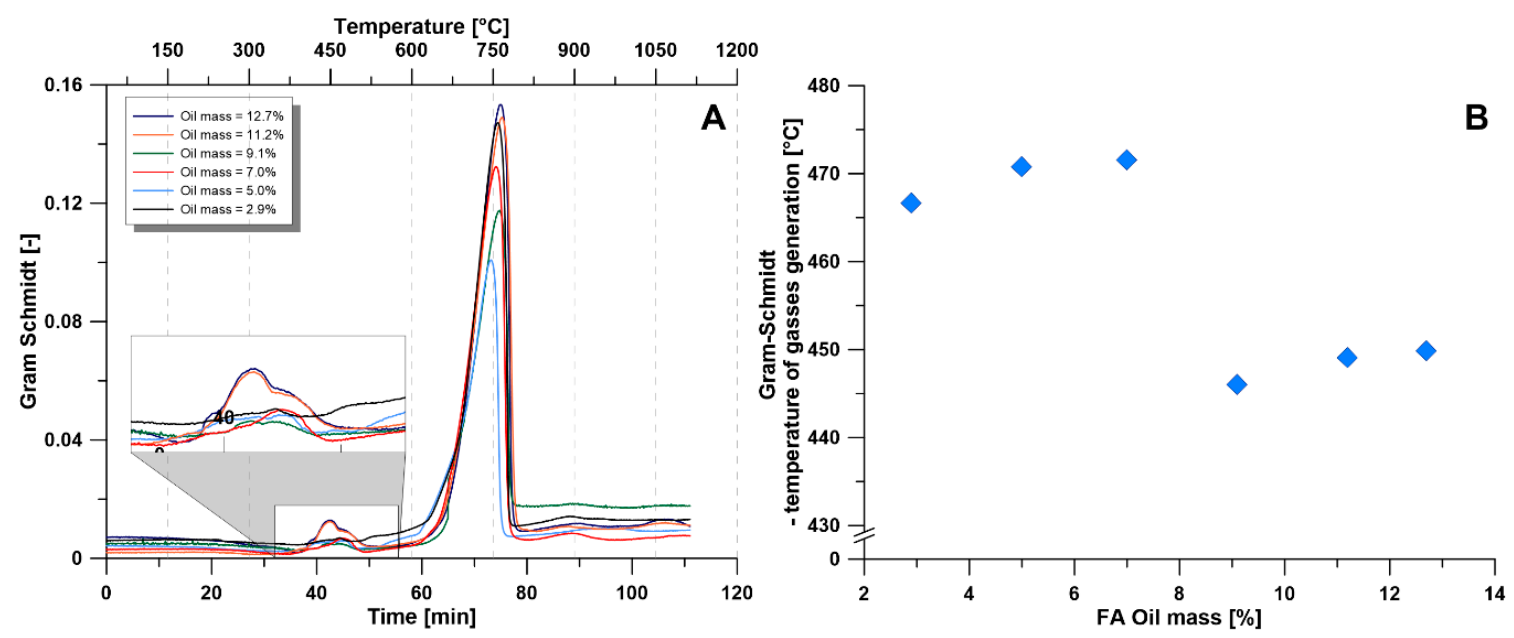

Figure 8. (A) Gram-Schmidt absorption intensity of evolved gases for the samples containing different levels of oil content. (B) Correlation of FA and Gram-Schmidt (temperature of gases generation).

\subsection{Elemental and Mineral Analysis}

Elemental analysis is an accurate standard method used for determining the carbon-hydrogen-nitrogen $(\mathrm{CHN})$ content of kerogens by combustion. However, it could be used for determining the origin and the evolution of oil shale with limited accuracy [2]. XRF was conducted to determine the major oxides present in the oil shale samples, whereas XRD was used as a qualitative analytical method for the identification of the crystal phase of minerals in the oil shale samples. SEM revealed information about the solid shale including outer morphology, chemical composition, crystalline structure, and orientation of materials making up the sample. EDX was one of the analytical techniques used for the elemental analysis or the chemical characterization of a sample. The interaction of a source of X-ray excitation and a sample gave a unique atomic structure for each element, which allowed a unique set of peaks on the electromagnetic emission spectrum.

\subsubsection{Elemental analysis}

CHN analysis was conducted for all oil shale samples (OS1 to OS6). Figure 9A shows a correlation between the FA (wt.\%) and the mass content of each element, where a directly proportional relationship between the two was observed. Out of the three possible correlations, elemental hydrogen mass content provided the best correlation to the FA with a good quadratic correlation $\left(R^{2}=0.98\right)$, as shown in Equation (3). Correlating the hydrogen content to the FA method is preferred because it is predominantly found in the organic matter (kerogen), while carbon is found in both inorganic and organic fractions.

$$
H=0.0208 \times F A^{2}-0.1849 \times F A+1.2392
$$

where $H$ represents the weight percent of hydrogen content in the oil shale sample, and $F A$ denotes the oil weight percent in the oil shale determined by the FA method.

Furthermore, the atomic ratios $\mathrm{H} / \mathrm{C}$ and N/C were calculated and evaluated against the oil content. There was a relatively fixed $\mathrm{N} / \mathrm{C}$ atomic ratio $(0.01-0.02)$, whereas a wider range of $\mathrm{H} / \mathrm{C}$ atomic ratio (0.69-1.12) was found. Values of the $\mathrm{H} / \mathrm{C}$ ratio could be used as a preliminary indicator of the aromatic nature of kerogen. However, the atomic ratios of $\mathrm{H} / \mathrm{C}$ and $\mathrm{O} / \mathrm{C}$ of the kerogen content (not the oil shale) could be assigned on the van Krevelen diagram to determine the type of kerogen [10]. It is reported that the kerogen of Jordanian oil shale has an average content of $10 \mathrm{wt} . \%$ and atomic $\mathrm{H} / \mathrm{C}$ and $\mathrm{O} / \mathrm{C}$ ratios of 1.3 and 0.101 , respectively [2]. 

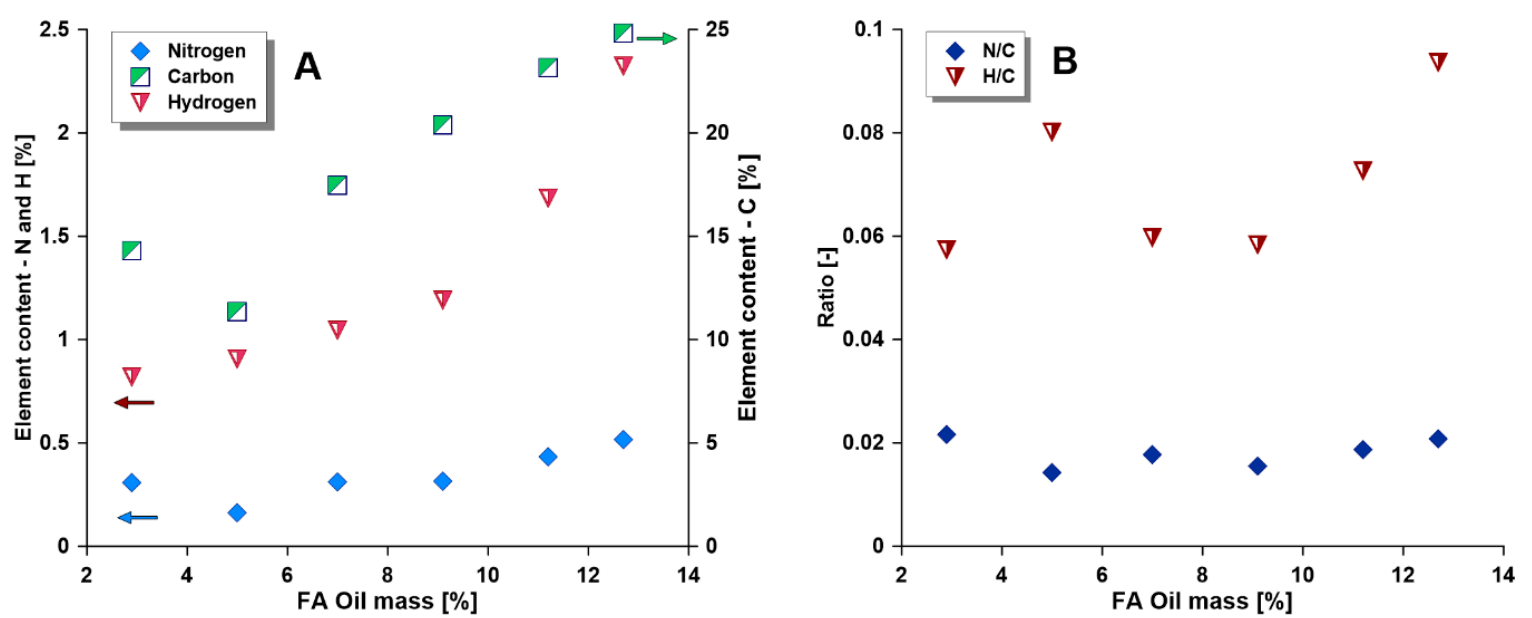

Figure 9. Relation between oil content in wt.\% from Fischer Assay and the (A) elemental analysis (wt.\%) of C, H, and $\mathrm{N}$ of solid oil shale samples, (B) atomic ratios of $\mathrm{H} / \mathrm{C}$ and N/C of the solid oil shale samples.

\subsubsection{XRF}

The XRF analysis of the mineral matter resulted from tested oil shale samples, as shown in Table 2, indicated that this oil shale contained mainly calcite $\left(\mathrm{CaCO}_{3}\right)$ and quartz $\left(\mathrm{SiO}_{2}\right)$. Furthermore, the data showed no trend in the mineral composition that could be correlated with the oil content. The mineral content of the tested samples agreed with the reported average mass concentrations of major inorganic content of oil shale deposits in the central part of Jordan [7].

Table 2. Comparative X-ray fluorescence (XRF) chemical composition in wt. $\%$ of investigated oil shale samples with different oil contents.

\begin{tabular}{cccccccccc}
\hline Sample & Shale Oil (wt. $\%)$ & $\mathbf{C a O}$ & $\mathbf{S i O}_{\mathbf{2}}$ & $\mathbf{A l}_{\mathbf{2}} \mathbf{O}_{\mathbf{3}}$ & $\mathbf{P}_{\mathbf{2}} \mathbf{O}_{\mathbf{5}}$ & $\mathbf{F e}_{\mathbf{2}} \mathbf{O}_{\mathbf{3}}$ & $\mathbf{M g O}$ & $\mathbf{K}_{\mathbf{2}} \mathbf{O}$ & $\mathbf{T i O}_{\mathbf{2}}$ \\
\hline OS1 & 2.9 & 41.0 & 10.7 & 3.83 & 1.77 & 1.71 & 0.58 & 0.34 & 0.11 \\
OS2 & 5.0 & 21.4 & 41.3 & 2.35 & 3.81 & 1.30 & 2.83 & 0.77 & 0.12 \\
OS3 & 7.0 & 44.6 & 3.97 & 1.19 & 8.51 & 0.61 & 0.12 & 0.01 & 0.02 \\
OS4 & 9.1 & 37.2 & 11.2 & 2.05 & 1.13 & 1.09 & 0.33 & 0.08 & 0.08 \\
OS5 & 11.2 & 36.9 & 7.76 & 1.21 & 0.83 & 0.73 & 0.39 & 0.09 & 0.05 \\
OS6 & 12.7 & 33.8 & 9.28 & 2.46 & 1.21 & 1.19 & 0.63 & 0.28 & 0.11 \\
\hline
\end{tabular}

\subsubsection{XRD}

XRD analysis of all oil shale samples (OS1 to OS6) showed the same type of minerals with different concentrations. In Figure 10, OS6 (FA $12.7 \mathrm{wt} . \%$ ) was used as an example to reveal the presence of the main minerals in the oil shale samples, which were quartz $\left(\mathrm{SiO}_{2}\right)$, ankerite $\left(\mathrm{Ca}(\mathrm{Fe}, \mathrm{Mg})\left(\mathrm{CO}_{3}\right)_{2}\right)$, calcite, apatite $\left(\mathrm{Ca}_{10}\left(\mathrm{PO}_{4}\right)_{6} \mathrm{~F}_{2}\right)$, and clay $\left(\mathrm{Mg}-\mathrm{SiO}_{2}-\mathrm{OH}-\mathrm{H}_{2} \mathrm{O}\right)$. 


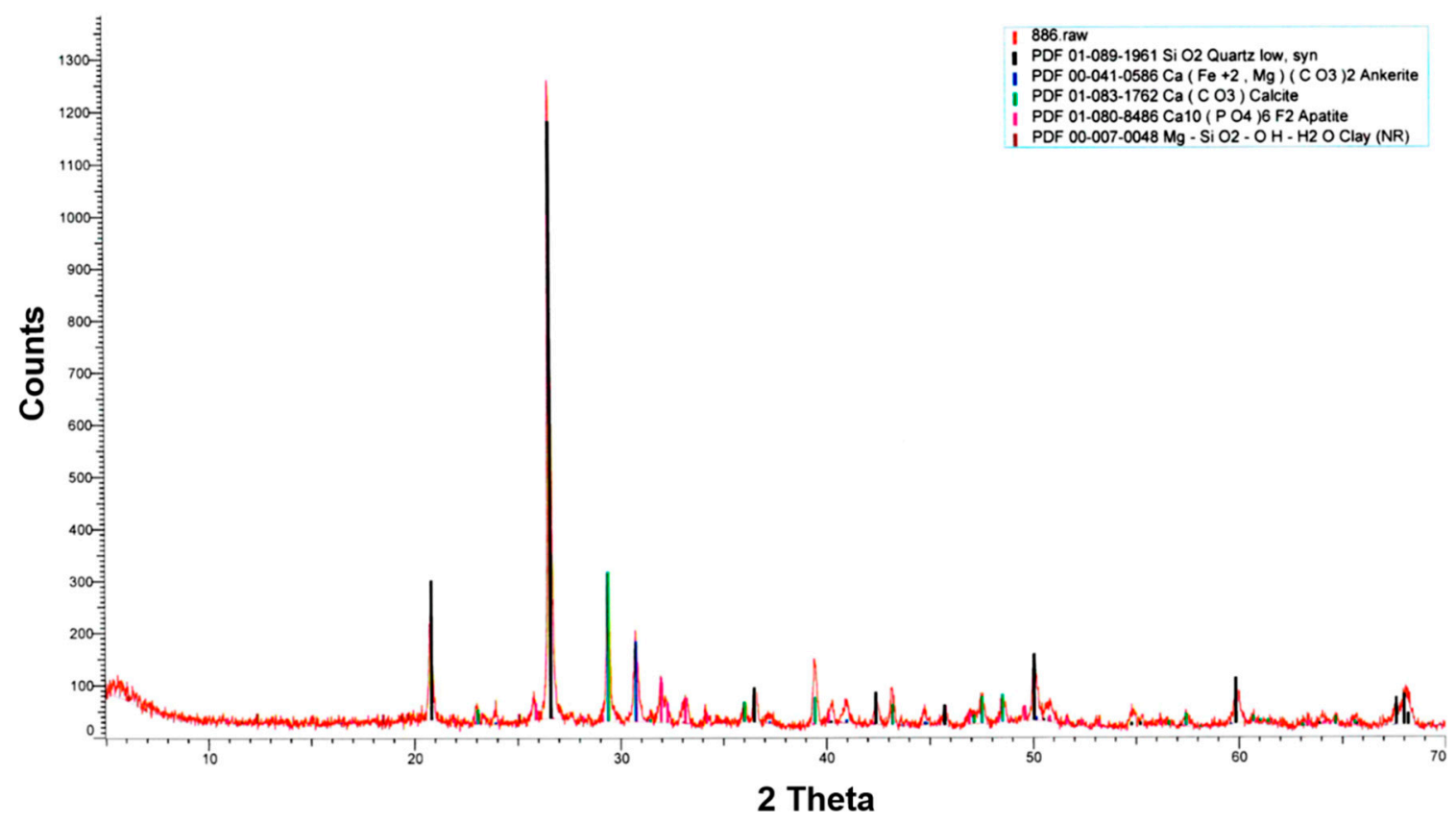

Figure 10. XRD analysis of raw oil shale sample (OS6 FA $12.7 \mathrm{wt} . \%$ ).

\subsubsection{SEM}

Figure 11 shows scanning electron micrographs for selected oil shale samples that covered the whole range of oil content given the symbols A (OS1 $2.9 \mathrm{wt} . \%)$, B (OS3 $7.0 \mathrm{wt.} \%$ ), and C (OS6 $12.7 \mathrm{wt.} \%$ ) with variable magnification from $1 \mathrm{kx}$ (magnification-1000 times) to $35 \mathrm{kx}$ (magnification-35,000 times). The three samples showed amorphous and fragmented surfaces with no distinct clusters of organic materials. EDX analysis (Figure 12) showed the same chemical components detected by XRF with no obvious trend that could be correlated with oil content, which might have been related to the anisotropy of the surface. Figure 13 shows the micrograph with colored mineral distribution mapped on the surface of oil shale and quantified at a rate of $10.67 \mathrm{Kcps}$ in a pulsed mode and multi-line scanning. It could be observed that the following elements, $\mathrm{C}, \mathrm{O}, \mathrm{Mg}, \mathrm{Al}, \mathrm{Si}, \mathrm{S}, \mathrm{K}, \mathrm{Ca}, \mathrm{Fe}, \mathrm{Cl}$, and $\mathrm{Zn}$, were uniformly distributed across the whole surface. Conversely, phosphorus $(\mathrm{P})$ was located in certain spots with less distribution because it originated from the apatite, as found in the XRD analysis. Calcium then silicon and sulfur were found at the highest level, which is in accordance with the literature values of Jordanian oil shale deposits $\left(30-35 \% \mathrm{CaCO}_{3}, 10-26.3 \% \mathrm{SiO}_{2}, 4.3-4.8 \% \mathrm{SO}_{3}\right)$ [7]. On the other hand, a more precise line scan analysis was conducted and is presented in Figure 14. The line analysis presented the same mineral types found by XRD and XRF analyses and showed no localization of the organic matter. Moreover, it demonstrated the diversity of mineral content and that there was no apparent relationship with the oil content. 

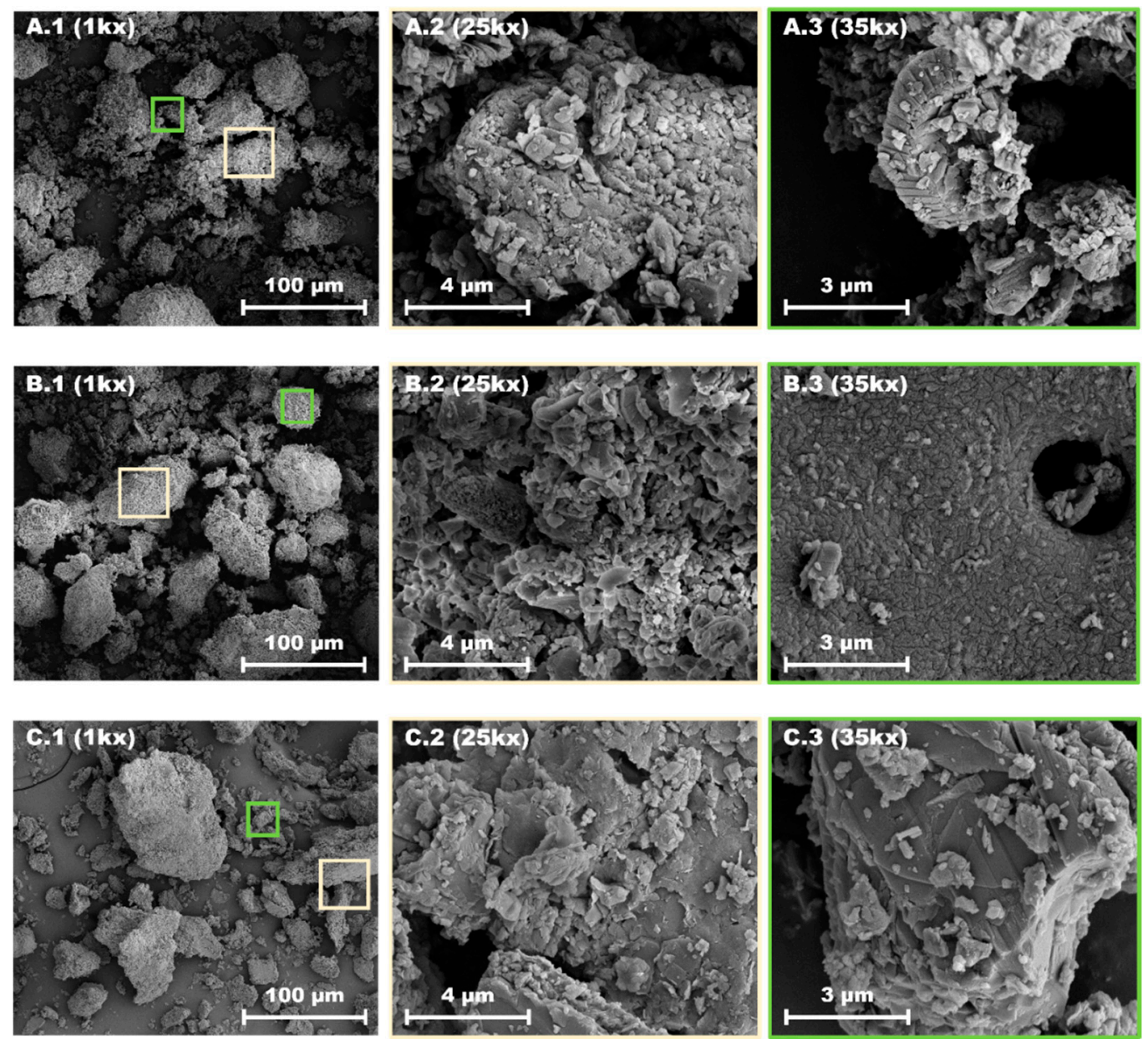

Figure 11. Scanning electron microscope (SEM) photos of samples containing A-2.9 wt. $\%$, B-7.0 wt.\%, and $\mathrm{C}-12.7 \mathrm{wt}$. $\%$ of oil shale.

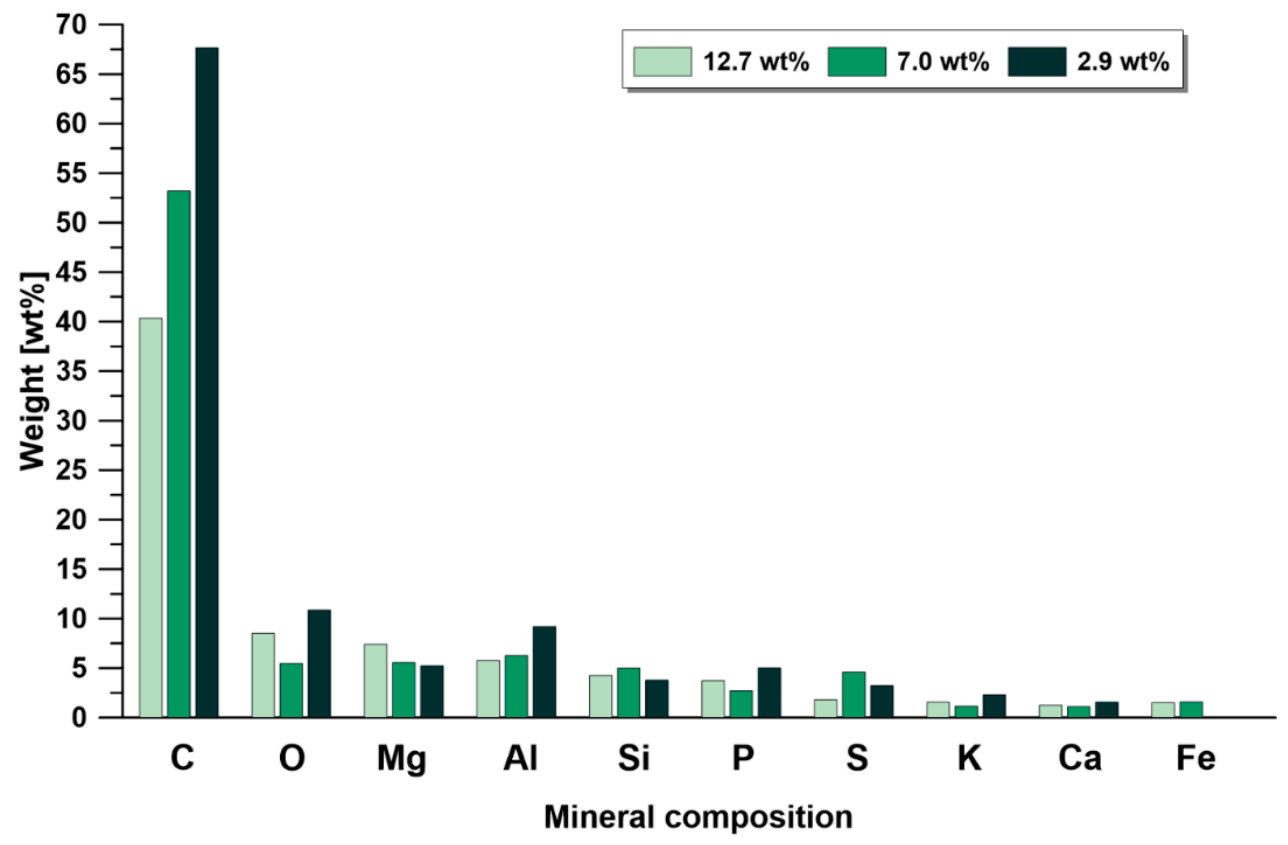

Figure 12. Comparative mass chemical composition of investigated oil shale samples with different oil content as determined by SEM. 

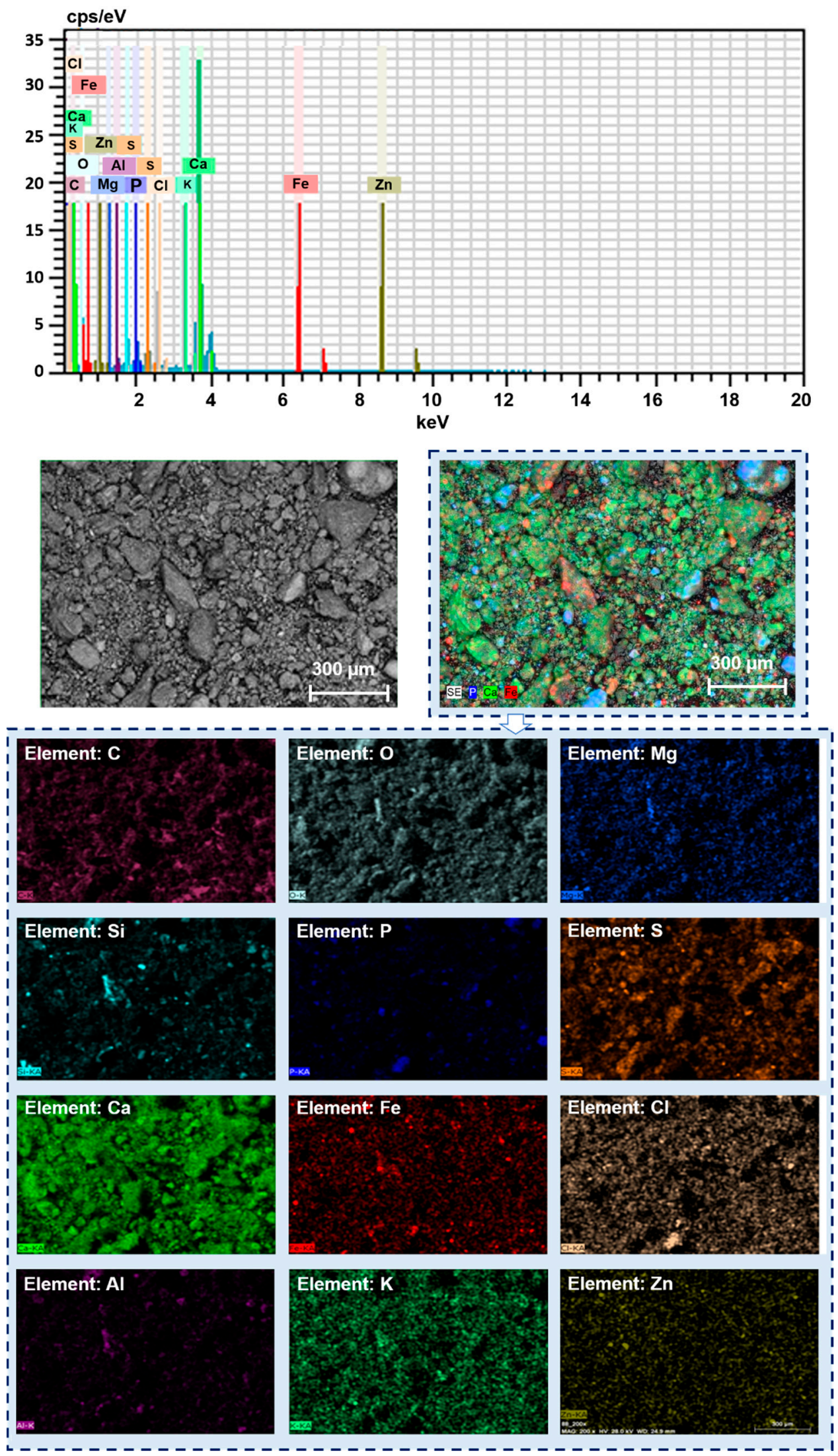

Figure 13. SEM identification of the chemical composition of OS3 with medium oil content (FA 7 wt.\%), showing micrograph with colored mineral distribution mapped and quantified at a rate of $10.67 \mathrm{Kcps}$ in a pulsed mode and multi-line scanning. 

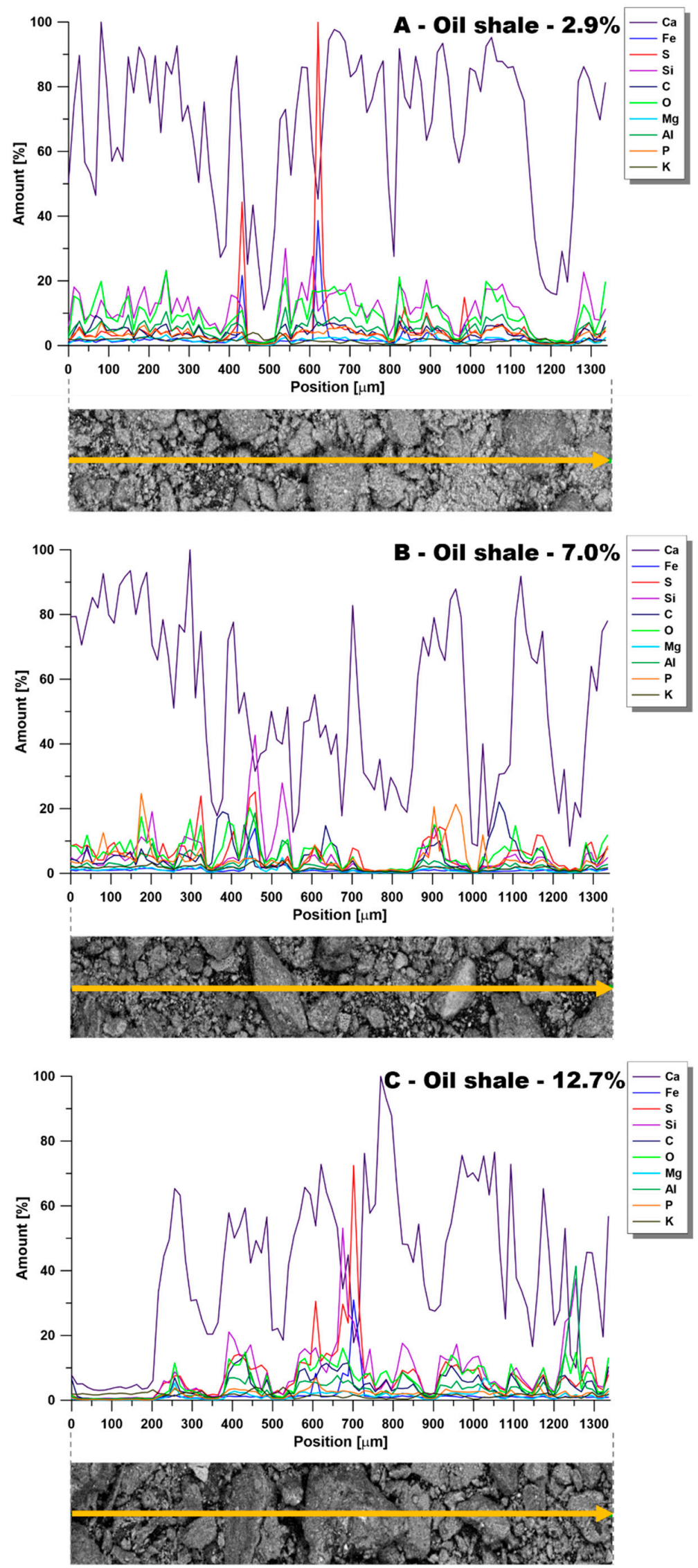

Figure 14. Line analyses of SEM with energy-dispersive X-ray (EDX) detector for $\mathbf{A}(12.5 \mathrm{wt} \%)$, B $(7.0 \mathrm{wt} \%)$, and C (2.9 wt\%) samples. 


\section{Conclusions}

In this work, several high throughput screening techniques for determining shale oil content were applied as an alternative for the conventional Fischer Assay (FA) method. The Omari oil shale deposit, which is located east of Jordan, was characterized and adopted as a case study. Under the test conditions, the following conclusions were drawn:

1. The TGA method could be used as an alternative method to the conventional FA method due to the high linear regression factor $\left(R^{2}=0.99\right)$ obtained between the weight loss of the organic content in the pyrolysis range $\left(370-560^{\circ} \mathrm{C}\right)$ obtained by the TGA and the oil yield (wt.\%) obtained by the FA method.

2. Elemental analysis could be used for replacing the conventional FA method. A good quadratic correlation $\left(R^{2}=0.98\right)$ was maintained between the FA and the hydrogen mass content.

3. The TGA-FTIR method could be used as another quick method for replacing the conventional FA method. A good quadratic correlation $\left(R^{2}=0.97\right)$ was maintained between the FA and the aliphatic hydrocarbons (FTIR peak at $2927 \mathrm{~cm}^{-1}$ ) produced in the pyrolysis zone.

4. XRF analysis of the mineral matter revealed that this oil shale contains mainly calcite and quartz with low concentrations of other metal oxides $\left(\mathrm{Al}_{2} \mathrm{O}_{3}, \mathrm{P}_{2} \mathrm{O}_{5}, \mathrm{Fe}_{2} \mathrm{O}_{3}, \mathrm{MgO}, \mathrm{K} 2 \mathrm{O}\right.$, and $\left.\mathrm{TiO}_{2}\right)$.

5. XRD analysis revealed the presence of the following minerals: quartz, ankerite, calcite, apatite, and clay, which matches oil shale composition.

6. SEM analysis revealed an amorphous oil shale surface with no distinct clusters of organic material, which was proven by area mapping and line analysis.

Author Contributions: Conceptualization, Z.A.E.-R., S.A.-G.; data curation, S.A.-G., J.K., Z.A.E.-R.; formal analysis, J.K., S.A.-G., F.Q., Z.A.E.-R.; funding acquisition, Z.A.E.-R.; investigation J.K., S.A.-G., Z.A.E.-R., E.A.; methodology S.A.-G., Z.A.E.-R.; project administration, Z.A.E.-R.; resources, Z.A.E.-R., S.A.-G., J.K.; supervision, Z.A.E.-R., S.A.-G.; validation, Z.A.E.-R., E.A., S.A.-G., J.K., N.A.-R.; visualization, J.K., Z.A.E.-R., E.A., N.A.-R., S.A.-G.; writing—original draft, Z.A.E.-R., S.A.-G., E.A., N.A.-R.; writing—review \& editing, Z.A.E.-R., S.A.-G., J.K., N.A.-R.

Funding: This research was funded by the German Jordanian University, project number SAMS 33/2016.

Acknowledgments: The authors would like to thank Jordan Oil Shale Company (JOSCO) for their support in providing the oil shale samples and their Fischer Assay analysis.

Conflicts of Interest: The authors declare no conflict of interest.

\section{References}

1. Energy 2018 - Facts and Figures; Ministry of Energy and Mineral Resources: Amman, Jordan, 2018.

2. Qian, J.; Yin, L. Oil Shale—Petroleum Alternative; Petroleum Industry Press: Beijing, China, 2010.

3. Wang, Q.; Hou, Y.; Wu, W.; Liu, Q.; Liu, Z. The structural characteristics of kerogens in oil shale with different density grades. Fuel 2018, 219, 151-158. [CrossRef]

4. Alali, J.; Salah, A.A.; Yasin, S.M.; Omari, W.A. Oil Shale; Ministry of Energy and Mineral Resources: Amman, Jordan, 2015.

5. El-Hasan, T.; Szczerba, W.; Buzanich, G.; Radtke, M.; Riesemeier, H.; Kersten, M. Cr(vi)/cr(iii) and As(v)/As(iii) ratio assessments in Jordanian spent oil shale produced by aerobic combustion and anaerobic pyrolysis. Environ. Sci. Technol. 2011, 45, 9799-9805. [CrossRef]

6. Alhilu, G. Jordanian Oil Shale 2019; Ministry of Energy and Mineral Resources: Amman, Jordan, 2019.

7. Jaber, J.O.; Probert, S.D. Exploitation of Jordanian oil-shales. Appl. Energy 1997, 58, 161-175. [CrossRef]

8. Zhang, Z.; Yang, X.; Jia, H.; Zhang, H. Kerogen beneficiation from longkou oil shale using gravity separation method. Energy Fuels 2016, 30, 2841-2845. [CrossRef]

9. Williams, P.F.V. Oil shales and their analysis. Fuel 1983, 62, 756-771. [CrossRef]

10. Korth, J. Analytical Studies on Australian Oil Shales. Ph.D. Thesis, University of Wollongong, Wollongong, Australia, 1987. 
11. Tian, S.; Dong, X.; Wang, T.; Zhang, R.; Zhang, P.; Sheng, M.; Cheng, S.; Zhao, H.; Fei, L.; Street, J.; et al. Surface properties of organic kerogen in continental and marine shale. Langmuir 2018, 34, 13882-13887. [CrossRef]

12. Foltin, J.P.; Lisboa, A.C.L.; de Klerk, A. Oil shale pyrolysis: Conversion dependence of kinetic parameters. Energy Fuels 2017, 31, 6766-6776. [CrossRef]

13. Bai, F.; Sun, Y.; Liu, Y.; Guo, M.; Zhao, J. Characteristics and kinetics of Huadian oil shale pyrolysis via non-isothermal thermogravimetric and gray relational analysis. Combust. Sci. Technol. 2019, 1-15. [CrossRef]

14. Hackley, P.C.; Lünsdorf, N.K. Application of raman spectroscopy as thermal maturity probe in shale petroleum systems: Insights from natural and artificial maturation series. Energy Fuels 2018, 32, 11190-11202. [CrossRef]

15. Lu, Z.Q.; Hai, X.Q.; Wei, J.X.; Bao, R.M. Characterizing of oil shale pyrolysis process with laser ultrasonic detection. Energy Fuels 2016, 30, 7236-7240. [CrossRef]

16. Budinova, T.; Razvigorova, M.; Tsyntsarski, B.; Petrova, B.; Ekinci, E.; Yardim, M.F. Characterization of Bulgarian oil shale kerogen revealed by oxidative degradation. Chemie Erde-Geochem. 2009, 69, 235-245. [CrossRef]

17. Stam, A.F.; Meij, R.; te Winkel, H.; van Eijk, R.J.; Huggins, F.E.; Brem, G. Chromium speciation in coal and biomass co-combustion products. Environ. Sci. Technol. 2011, 45, 2450-2456. [CrossRef] [PubMed]

18. Li, Z.-K.; Wei, X.-Y.; Yan, H.-L.; Zong, Z.-M. Insight into the structural features of zhaotong lignite using multiple techniques. Fuel 2015, 153, 176-182. [CrossRef]

19. Salmon, E.; Behar, F.; Hatcher, P.G. Molecular characterization of type I kerogen from the green river formation using advanced NMR techniques in combination with electrospray ionization/ultrahigh resolution mass spectrometry. Org. Geochem. 2011, 42, 301-315. [CrossRef]

20. Kelemen, S.R.; Afeworki, M.; Gorbaty, M.L.; Sansone, M.; Kwiatek, P.J.; Walters, C.C.; Freund, H.; Siskin, M.; Bence, A.E.; Curry, D.J.; et al. Direct characterization of kerogen by $\mathrm{x}$-ray and solid-state ${ }^{13} \mathrm{C}$ nuclear magnetic resonance methods. Energy Fuels 2007, 21, 1548-1561. [CrossRef]

21. Chu, W.; Cao, X.; Schmidt-Rohr, K.; Birdwell, J.E.; Mao, J. Investigation into the effect of heteroatom content on kerogen structure using advanced ${ }^{13} \mathrm{C}$ solid-state nuclear magnetic resonance spectroscopy. Energy Fuels 2019, 33, 645-653. [CrossRef]

22. Siramard, S.; Bunman, Y.; Lai, D.; Xu, G. Pyrolysis of Huadian oil shale in an infrared heating reactor. Energy Fuels 2017, 31, 6996-7003. [CrossRef]

23. Xu, S.; Zeng, X.; Han, Z.; Cheng, J.; Wu, R.; Chen, Z.; Masĕk, O.; Fan, X.; Xu, G. Quick pyrolysis of a massive coal sample via rapid infrared heating. Appl. Energy 2019, 242, 732-740. [CrossRef]

24. Siramard, S.; Zhan, J.-H.; Han, Z.; Xu, S.; Mašek, O.; Xu, G. Secondary cracking of volatile and its avoidance in infrared-heating pyrolysis reactor. Carbon Resour. Convers. 2018, 1, 202-208. [CrossRef]

25. Luo, X.; Guo, Q.; Zhang, D.; Zhou, H.; Yang, Q. Simulation, exergy analysis and optimization of a shale oil hydrogenation process for clean fuels production. Appl. Therm. Eng. 2018, 140, 102-111. [CrossRef]

26. Dyni, J.R. Geology and Resources of Some World Oil-Shale Deposits; 2005-5294; U.S. Department of the Interior: Washington, DC, USA, 2006; p. 49. Available online: https://pubs.usgs.gov/sir/2005/5294/pdf/sir5294_508.pdf (accessed on 8 August 2019).

27. Standard Test Method for Oil from Oil Shale (Resource Evaluation by the Fischer Assay Procedure; ASTM: D 3904-90; ASTM International: West Conshohocken, PA, USA, 1990.

28. Williams, P.F.V. Thermogravimetry and decomposition kinetics of British Kimmeridge clay oil shale. Fuel 1985, 64, 540-545. [CrossRef]

29. Mingshu, C.; Xiyan, L.; Hongpeng, L.; Yang, X.; Qing, W. Gaseous emission and thermal analysis during co-combustion of oil shale semi-coke and sawdust using TG-FTIR. Oil Shale 2015, 32, 356-372. [CrossRef]

(C) 2019 by the authors. Licensee MDPI, Basel, Switzerland. This article is an open access article distributed under the terms and conditions of the Creative Commons Attribution (CC BY) license (http://creativecommons.org/licenses/by/4.0/). 